\title{
SiM
}

\section{Assessing the Past}

\section{The Importance of Cultivation History in EBIPM Success}

\author{
By Lesley R. Morris and Thomas A. Monaco
}

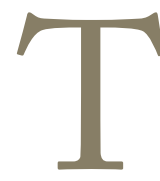

he introduction and spread of invasive plants has been consistently linked to the development of agricultural crops such as cereal grains, legumes, and forage grasses. This is because cultivating a crop involves both soil disturbance (e.g., plowing and harrowing) and the introduction of plant species, both the intended crop and unintended contaminants that accompany crop seed. ${ }^{1}$ Cultivation is also consistently linked with the creation of land-use legacies, which continue to impact ecosystem structure and function for long periods of time following human utilization of resources. These land-use legacies can alter soils, hydrology, and plant communities in ways that persist for decades, centuries, and even millennia., ${ }^{2,3}$ common legacy of cultivation is invasive plant species dominance, causing the site to remain "stuck" in a state of arrested succession with early-seral weedy species dominating for decades.

The connection between cultivation legacies and an invasive species is widely exemplified by cheatgrass (Bromus tectorum) in the western United States. Cheatgrass was spread widely as a contaminant with winter-wheat seed and got its name from "cheating" farmers out of their seed and their desired crop. ${ }^{4}$ Like winter wheat, cheatgrass is a winter annual that can germinate and survive cold temperatures in late winter and early spring, and is the first grass species to emerge and take advantage of the early snow melt moisture and soil nutrients. Its connection to cultivation brought cheatgrass to the western states, and settlement through homesteading facilitated its spread.,4

In the western United States, livestock grazing and cultivation were the primary land uses during settlement. However, cultivation was the only land use that became a codified requirement in the homesteading laws that allowed US citizens to obtain land from the federal government. The Homestead Act of 1862 required proof of cultivation but, it was the Enlarged Homestead Act of 1909 that specifically mandated at least 20 acres be cultivated by the second year and 40 acres be continuously cultivated until the final year of patent. ${ }^{5}$ The cultivation mandate was a product of the popularity and promotion of dry farming (agriculture without irrigation) in the United States. ${ }^{5,6}$ The combination of promotion, legislation, and economics made the Enlarged Homestead Act the most popular of all the federal provisions to transfer federal lands into private owner- ship in the West. In the first year of its passage, applications for patents were filed for over 18 million acres of land, and applications for homesteads peaked in the following decade. ${ }^{6} \mathrm{With}$ the United States entry into World War I, cultivation took on an additional patriotic meaning as a way to support the war effort (Figure 1). Similarly, it was a combination of factors that drove widespread abandonment of dry farms, including falling wheat prices, drought, and the use of submarginal lands for this form of cultivation (Figure 2). As a result, there are millions of acres of formerly cultivated land across the western United

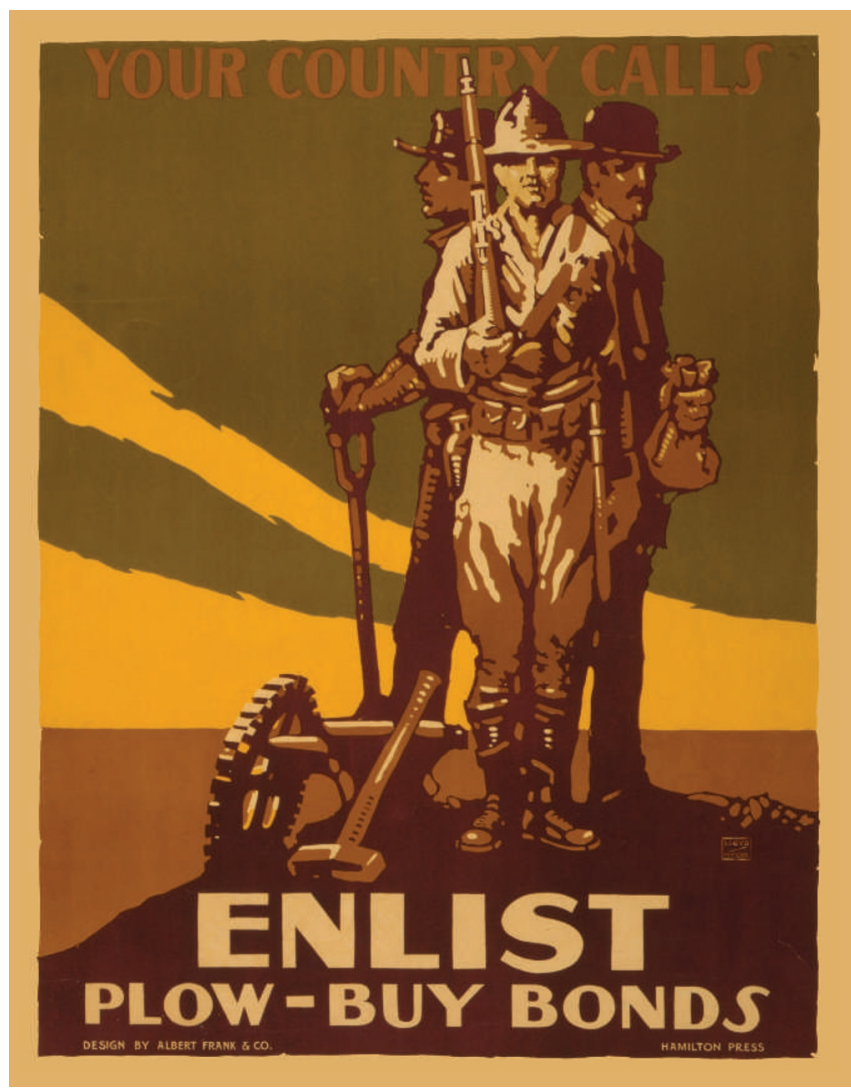

Figure 1. The United State's entrance into World War I promoted cultivation, in part because it was encouraged as a patriotic way to support the war effort (Library of Congress, Prints and Photographs Division, WWI Posters, LC-USZC4-7817). 


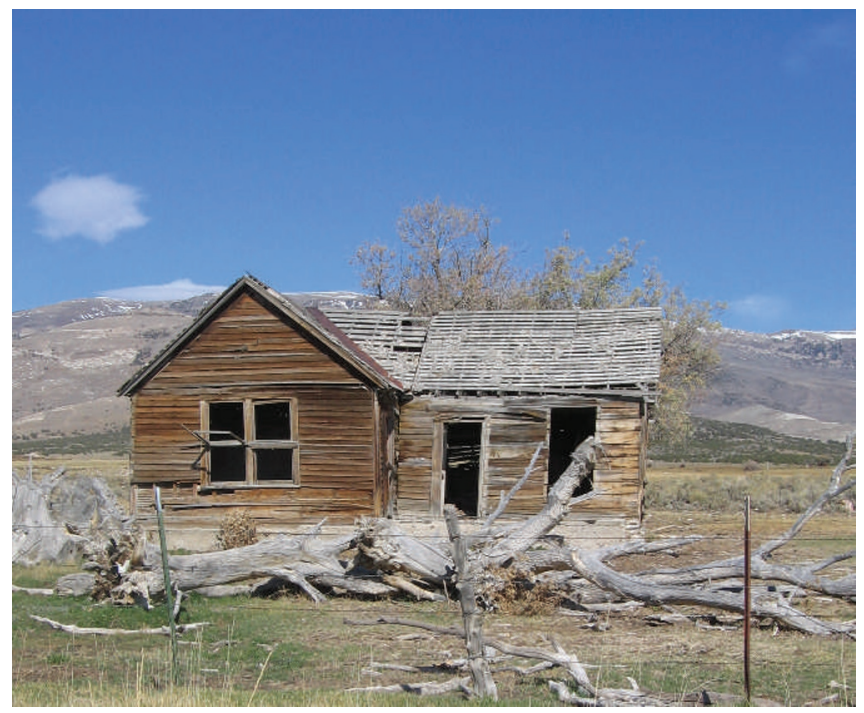

Figure 2. Many of the dry farming homesteads, such as this one in Oneida County, ID, were abandoned by the 1930s due to a combination of factors, including falling wheat prices and drought, and because the land was submarginal for cultivation.

States where the material evidence (e.g., homesteads, corrals) has faded from the landscape, but the cultivation legacies remain. ${ }^{7}$ Sometimes the old fields are difficult to identify on the ground but are easily visible in aerial photographs, even nearly a century after cultivation has ceased (Figure 3$)^{7}$

These cultivation legacies are often overlooked, yet land-use history is an important driver of plant community diversity and structure, hydrological function, and nutrient distribution and cycling. ${ }^{2}$ Cultivation creates altered sites because the anthropogenic disturbances associated with this land use (e.g., plowing, fertilizing) are unlike any other natural disturbance regime these systems and plant communities experienced during their evolution. ${ }^{8}$ These anthropogenic disturbances are contemporary additions to the ecosystem outside of the magnitude and frequency of natural disturbance regimes. They also can result in modification of the ecosystem and irreversible species loss because the environment becomes mismatched with the specific growth requirements for a plant species. ${ }^{9}$ These cultivation legacies can represent novel environmental conditions that are initiated by the disturbance and maintained at the site through feedbacks between biotic and abiotic processes.

\section{Where Cultivation History Fits in the EBIPM Model}

Given the tendency for cultivation to leave land-use legacies that include altered ecosystem functioning, locating and evaluating historical cultivation is an important part of the first two steps of the Ecologically Based Invasive Plant Management (EBIPM) model.

\section{Step 1: Assessing Rangeland Health}

In Step 1, a Rangeland Health Assessment is completed. This assessment is a qualitative evaluation of ecosystem at- tributes in comparison to reference conditions using 17 indicators of soil stability, hydrologic function, and biological integrity (e.g., bare ground, rills, and plant function/structural groups).${ }^{10}$ Areas of historical cultivation need to be identified in order to fully complete an assessment because this land use might have created sites that fundamentally depart from rangeland health of reference areas within the same property boundaries, and should be assessed separately. ${ }^{11}$ Locating historical cultivation can be accomplished using historical archives (e.g., homestead records) and aerial photographs. ${ }^{12}$

Without knowing and assessing cultivation history, it would be easy to misinterpret site departure from the reference area during the initial Rangeland Health Assessment. If a Rangeland Health Assessment were completed on the property in Figure 3, the outcome could be very different between the old field and the noncultivated land surrounding it. Indicators of rangeland health (e.g., bare ground, pedestals, water flow patterns, and rills) can have even more departure from the reference area on cultivated land than noncultivated land. For instance, one of the 17 indicators used in a Rangeland Health Assessment is the percentage of bare ground. ${ }^{10}$ According to the reference indicator for this site, percentage of bare ground is expected to be between $25-30 \%{ }^{13}$ The percentage of bare ground in the noncultivated land measured $39 \%$, which may be considered "slightly to moderately higher than expected" and would rank as slight to moderate. In contrast, the percentage of bare ground in the old field measured $55 \%$, which can be considered "much higher than expected" and would potentially be ranked as extreme departures from the reference area. ${ }^{10}$ Cultivation legacies can lead to more extreme departure from the reference areas for all 17 indicators.

\section{Step 2: Indentifying the Causes of Change in Need} of Repair

In Step 2, the causes of invasion and associated nonfunctioning processes are identified.

Because legacies of historical cultivation can last for decades to centuries, they also alter the three causes of plant succession: species availability, site availability, and species performance. ${ }^{14,15}$

Site availability. Site availability means there are favorable locations in the soil for germination and establishment of plants. Cultivation legacies can change the soil surface of plant communities, which reduce available safe sites for seed germination and seedling establishment. These legacies can include an increase in soil compaction (e.g., bulk density) and greater surface penetration resistance that create physical barriers to seedling emergence, impede root growth, and retard plant development. ${ }^{16}$ Compaction layers formed beneath the soil surface, known as plow pans, also restrict root growth. ${ }^{16}$ Soil compaction also can have hydrologic impacts on infiltration, soil water holding capacity, and runoff. Cultivation legacies can have a greater effect on differences in soil water movement between plowed and unplowed sites than the differences in soil water movement between two soil series. ${ }^{17}$ Water content and availability to plants 

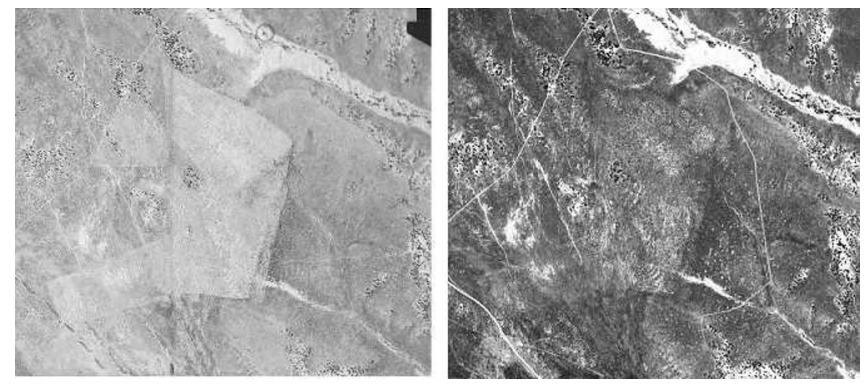

Figure 3. Although old fields can be difficult to see at ground level, they are often still visible in aerial photos even nearly a century after cultivation ceases. The old field in this photo was abandoned in the 1920s and was still visible from the air after 30 years (1953; left) and after about 90 years (2011; right). (Photos from BLM Salt Lake Field office and Google Earth.)

also can be reduced by soil compaction in old fields. ${ }^{18}$ Because compaction can differentially favor some species and growth forms over others, it can change the potential trajectory of plant communities when site availability is altered. ${ }^{19}$

Species availability. Species availability refers to the presence of seeds (or bulbs) that are dispersed to a site or that are already a part of the seed bank. Native species in stable environments do not typically form long-lasting seed banks, and even when they do, the mechanical action of plowing can bury and damage seeds. ${ }^{20}$ Seed longevity determines their survival beyond the duration of cultivation, and the seed robustness determines if they can survive cultivation intensity. ${ }^{21}$ Consequently, native seed banks tend to be impoverished by cultivation, whereas agricultural weeds form persistent soil seed banks that are more likely to dominate the seed bank after abandonment of cultivation. ${ }^{22}$ Species availability after cultivation is abandoned is further limited by dispersal and reproduction. Many herbaceous species with limited or unassisted dispersal can be underrepresented in formerly cultivated land. ${ }^{23}$ For example, because cultivation removes the whole plant, species that reproduce asexually through vegetative growth are less likely to occupy old fields. ${ }^{21,23}$

Species performance. Species performance refers to the processes that control plant growth and productivity. Cultivation legacies can affect species performance by changing the content and distribution of soil resources necessary for plant growth. Cultivation-induced changes to soil fertility include reduced soil organic matter and soil organic carbon, and either depleted or enhanced soil nutrients. Old fields often have altered soil organic carbon and soil nutrients. ${ }^{3}$ Even prehistoric old fields in the American Southwest have been found to contain lower soil organic carbon 1,000 years after cultivation ceased. ${ }^{24}$ Soil nutrient loss due to cropping can stem from both reduced soil organic material and the loss of topsoil during wind and water erosion. However, soil organic carbon and nutrients can remain elevated in old fields from the historic application of either organic (e.g., manure and ash) or inorganic fertilizers. ${ }^{3}$ Cultivation legacies also can affect the distribution of soil nutrients because vertical and horizontal mixing homogenizes soil resources, which can re-

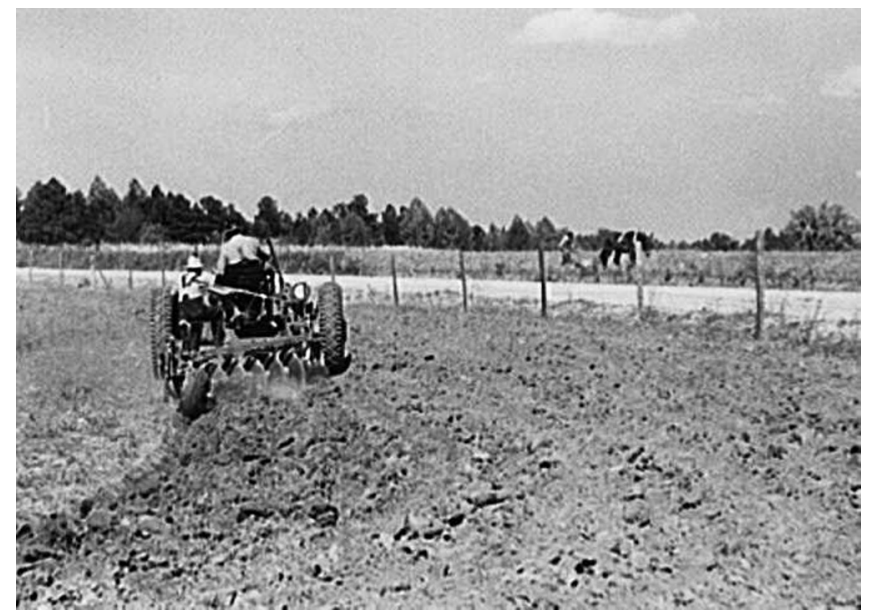

Figure 4. Even when cultivation takes place on the same soil type on adjacent properties, legacies can be different because of difference in historical farming practices and management. For example, horse-drawn plows can leave different legacies in soils than tractor-drawn plows (Library of Congress, Prints and Photographs Division, FSA/OWI Collection, LC-USF34-051265-D).

duce establishment niches for desirable species and contribute to the dominance of nonnative annuals in old fields.

\section{Factors Influencing Cultivation Legacies}

Cultivation legacies are not always predictable and can vary with both environmental and historical factors. Some ecosystems are more susceptible than others to agricultural land-use legacies because of inherent characteristics of the soils and the plant community. ${ }^{20}$ For example, places less suitable for agriculture are prone to greater legacies because they require higher modification of the site for successful agriculture (e.g., fertilization, irrigation, ground water pumping). ${ }^{20}$ Cultivation legacies are also highly variable due to historical factors such as length of use, time since abandonment, and historical management. The longer a site was cultivated the more pronounced many of the alterations become, including more impoverished native seed banks and an increased need for control of nonnative species. ${ }^{21}$ Additional years of cultivation can also result in greater soil compaction, severely eroded surface horizons, and reduced organic matter. ${ }^{25}$ In addition, the most recently abandoned old fields often have the least similarity to a natural vegetation state, which then improves with time since abandonment. ${ }^{26}$ However, the legacy and recovery from cultivation can be different between old fields in the same soil type because of differences in historical uses of machinery, techniques, and practices between farmers (Figure 4). ${ }^{22}$

\section{Conclusion}

Historical cultivation can create land-use legacies that persist for decades to centuries. These legacies play an important part in the invasion and dominance of invasive plants. Because previously cultivated sites can be altered in unique ways, it is important to identify and evaluate them separately from noncultivated lands. Knowing if an area has been cultivated will help identify 
which of the three causes of plant community change have been affected, and which ecological processes are in need of repair.

\section{Acknowledgments}

We would like to thank Roger Sheley and Brenda Smith for the invitation to participate in this special issue. We also appreciate the comments of the two anonymous reviewers on an earlier draft of this manuscript.

\section{References}

1. Mack, R. N. 1989. Temperate grasslands vulnerable to plant invasions: characteristics and consequences. In: J. A. Drake, H. A. Mooney, F. di Castri, R. H. Groves, F. J. Kruger, M. Rejmánek, and M. Wiliamson [EDs.] Biological invasions: a global perspective. Chichester, UK: John Wiley and Sons. p. 155-173.

2. Foster, D., F. Swanson, J. Aber, I. Burke, N. Brokaw, D. TilMAN, AND A. KnApr. 2003. The importance of land-use legacies to ecology and conservation. BioScience 53:77-88.

3. McLauchlan, K. 2006. The nature and longevity of agricultural impacts on soil carbon and nutrients: a review. Ecosystems 9:1364-1382.

4. Maск, R. N. 1981. Invasion of Bromus tectorum L. into western North America: an ecological chronicle. Agro-Ecosystems 7:145-165.

5. Peffer, E. L. 1972. The closing of the public domain: disposal and reservation policies 1900-50. New York, NY, USA: Arno Press. 372 p.

6. Gates, P.W.1968. History of public land law development. Washington, DC, USA: Public Land Law Review Commission. 828 p.

7. Morris, L. R. 2011. Land-use legacies of cultivation in shrublands: ghosts in the ecosystem. In: T. A. Monaco, E. W. Schupp, R. L. Pendleton, S. G. Kitchen, and P. K. Palacios [comps]. Proceedings of the 16th Wildland Shrub Symposium: Threats to Shrubland Ecosystem Integrity; 18-20 May 2010; Logan, UT, USA. Logan, UT, USA: S. J. and Jessie E. Quinney Natural Resources Research Library. Natural Resources and Environmental Issues Vol. XVII. p. 11-16.

8. McIntyre, S., And R. J. Новвs. 1999. A framework for conceptualizing human effects on landscapes and its relevance to management and restoration. Conservation Biology 13:1282-1292.

9. Byers, J. E. 2002. Impact of non-indigenous species on natives enhanced by anthropogenic alteration of selection regimes. Oikos 97:449-458.

10. Pyke, D. A., J. E. Herrick, P. Shaver, and M. Pellant. 2002. Rangeland health attributes and indicators for qualitative assessment. Journal of Range Management 55:584-597.

11. Morris, L. R., T. A. Monaco, and R. L. Sheley. 2011. Landuse legacies and vegetation recovery 90 years after cultivation in Great Basin sagebrush ecosystems. Rangeland Ecology \& Management 64:488-497.

12. Morris, L. R. 2012. Using homestead records and aerial photos to investigate historical cultivation in the United States. Rangelands 34(2):12-17.

13. USDA-NRCS. 1993. Utah ecological site descriptions. Available at: http://www.ut.nrcs.usda.gov/technical/technology/range/ mlra28a.html. Accessed 25 July 2010.
14. Pickett, D. A., S. L. Collins, and J. J. Armest. 1987. Model, mechanisms, and pathways of succession. Botanical Review 53:335-371.

15. Sheley, R. L., J. A. Mangold, And J. L. Anderson. 2006. Potential for successional theory to guide restoration of invasiveplant-dominated rangeland. Ecological Monographs 76:365-379.

16. Unger, P. W., and T. C. Kaspar. 1994. Soil compaction and root growth: a review. Agronomy Journal 86:759-766.

17. Schwartz, R. C., S. T. Evett, and P. S. Unger. 2003. Soil hydraulic properties of cropland compared with reestablished and native grasslands. Geoderma 116:47-60.

18. Standish, R. J., V. A. Cramer, R. J. Нobbs, and H. T. Kobryn. 2006. Legacy of land-use evident in soils of Western Australia's wheatbelt. Plant and Soil 280:189-207.

19. Parker, J. D., L. J. Richie, E. M. Lind, and K. O. Maloney. 2010. Land use history alters the relationship between native and exotic plants: the rich don't always get richer. Biological Invasions $12: 1557-1571$.

20. Cramer, V. A., R. J. Нobbs, and R. J. Standish. 2008. What's new about old fields? Land abandonment and ecosystem assembly. Trends in Ecology and Evolution 23:104-112.

21. Standish, R. J., V. A. Cramer, S. L. Wild, and R. J. Нobbs. 2007. Seed dispersal and recruitment limitation are barriers to native recolonization of old-fields in western Australia. Journal of Applied Ecology 44:435-445.

22. Buisson, E., And T. Dutoit. 2004. Colonisation by native species of abandoned farmland adjacent to a remnant patch of Mediterranean steppe. Plant Ecology 174:371-384.

23. Dyer, J. M. 2010. Land-use legacies in a central Appalachian forest: differential response of trees and herbs to historic agricultural practices. Applied Vegetation Science 13:195-206.

24. Sandor, J. A., P. L. Gersper, and J. W. Hawley. 1986. Prehistoric agricultural terraces and soils in the Mimbres area, New Mexico. World Archeology 22:70-86.

25. Jenkins, M. A., and G. R. Parker. 2000. The response of herbaceous-layer vegetation to anthropogenic disturbance in intermittent stream bottomland forests of southern Indiana, USA. Plant Ecology 151:223-237.

26. Öster, M., K. Ask, S. A. O. Cousins, and O. Eriksson. 2009. Dispersal and establishment limitation reduces the potential for successful restoration of semi-natural grassland communities on former arable fields. Journal of Applied Ecology 46:1266-1274.

Authors are Post-Doctoral Research Associate,LesleyRMorris@ gmail.com (Morris) and Research Ecologist (Monaco), USDAARS Forage and Range Research Laboratory, Utah State University, 696 North 1100 East, Logan, UT 84322-6300, USA. This research was funded by the USDA-ARS Area-Wide Ecologically Based Invasive Plant Management (EBIPM) project. Mention of a proprietary product does not constitute a guarantee or warranty of the product by USDA or the author, and does not imply its approval to the exclusion of the other products that also may be suitable. 